\title{
The Use of Yellow Kepok Banana Peel Extract (Musa paradisiaca L. var bluggoe) as an Antibacterial for Chronic Periodontitis Caused by Porphyromonas gingivalis
}

\author{
Viranda Sutanti ${ }^{1 *}$, Arum Anugrah Destyawati ${ }^{2}$ \\ ${ }^{1}$ Department Oral Biology, Faculty of Dentistry, Universitas Brawijaya \\ Jalan Veteran Malang East Java Indonesia 65145 \\ ${ }^{2}$ Undergraduate Program, Faculty of Dentistry, Universitas Brawijaya \\ Jalan Veteran Malang East Java Indonesia 65145
}

Submission: September 2019; Revised: September 2019: Accepted: October 2019

*Corresponding author: Viranda Sutanti; e-mail: virandasutanti@ub.ac.id; tel.: 0823-3114-3535

\begin{abstract}
Chronic periodontitis is the most common periodontal disease, and Porphyromonas gingivalis is its dominant causative microorganism. Yellow kepok banana peel (Musa paradisiaca L. var. Bluggoe) contains flavonoids, alkaloids, tannins, saponins and triterpenoids that can inhibit and kill Porphyromonas gingivalis. To reveal the antibacterial effectiveness of yellow kepok banana peel extract against Porphyromonas gingivalis. This is true experimental research employing the post-test only control group approach. Preliminary research was conducted to determine the concentration of the sample group. The study used 6 treatment groups of which the peel extract concentrations were 17.5\%, 15\%, $12.5 \%$, $10 \%, 7.5 \%, 5 \%$ and also 2 control groups. Yellow kepok banana peel extract was obtained through the maceration method using methanol as a solvent. The antibacterial activity was identified using the tube dilution method. Data analysis was conducted through the Kruskal Wallis test, the Mann Whitney test, and the Spearman correlation test. Minimum Inhibitory Concentration (MIC) is obtained at a concentration of 10\%, while the Minimum Bactericidal Concentration (MBC) is obtained at a concentration of $17.5 \%$. The test results of tube turbidity statistics indicated that there were significant differences in each extract concentration (Kruskal Wallis, $p=0,011)$ and there was a relationship between the concentration variables and the turbidity of the tubes (Spearman, correlation coefficient $=0,790$ ). The statistical test results of the colony growth revealed that there were significant differences in each extract concentration (Kruskal wallis, $p=0,005)$ and there was a relationship between the concentration variables and the growth of bacterial colonies (Spearman, correlation coefficient $=-0,977)$. Yellow kepok banana peel extract (Musa paradisiaca L. var. Bluggoe) is effective to use as antibacterial for chronic periodontitis caused by Porphyromonas gingivalis.
\end{abstract}

Keywords: MIC; MBC; Yellow kepok banana peel; Porphyromonas gingivalis.

\section{INTRODUCTION}

Chronic periodontitis is the most common periodontal disease with which Porphyromonas gingivalis is the dominant causative microorganism [1]. In the case of periodontitis, using a mouthwash containing Chlorhexidine is commonly practiced to suppress the growth of Porphyromonas gingivalis [2]. The side effects are tooth discoloration, changes in taste, ulcers and allergic reactions; these increase the use of alternative mouthwash made from herbal ingredients $[3,4]$

Herbal ingredients are found in fruits, one of which is a banana. Indonesia is one of six banana producing countries in the world; Malang Regency is one of the biggest contributors producing 710,040 tons of bananas [5]. Bananas often leave peel waste which has not been optimally used. It is found that the peels have better antibacterial activity against Staphylococcus aureus (Gram-positive) and Pseudomonas aeruginosa (Gram-negative) than other parts of the banana [6].
Yellow Kepok Banana (Musa paradisiaca L. var. Bluggoe) is quite popular to Indonesian people. In the phytochemical results, this type of banana was selected as its peel extract indicated the presence of triterpenoid compounds which were not found in $u l i$ banana and jackfruit banana peel extracts [7]. The results indicated that the yellow kepok Banana peel had active flavonoids, alkaloids, tannins, saponins, and triterpenoids, which are the compounds that have antibacterial and antifungal abilities [9] There has not been further research related to yellow kepok banana peel extract (Musa paradisiaca L. var. Bluggoe) against Porphyromonas gingivalis; this what makes the research essential as it is expected that the results would optimize the use of peel waste.

\section{METHODS}

\section{Materials and bacteria selection.}

Raw yellow kepok banana peels were separated from the fruit, washed and completely dried in the sun (until they were no longer watery), then blended 
to powder. The peels underwent plant determination process at UPT (the technical implementation unit) Materia medica in Batu, Malang, of which the registration number is 074/289A/102.7/2018. Porphyromonas gingivalis was obtained from the Microbiology Laboratory of the Faculty of Medicine, Universitas Brawijaya. Bacterial isolates were tested for gram staining identification, as well as catalase, oxidase, and indole tests.

\section{Extraction Procedures.}

1000 grams of dried raw yellow kepok banana peel powder was extracted through the maceration method, using a 7-liter methanol solvent and evaporated for 5 hours to produce a $30-\mathrm{ml}$ extract. The peel extract colour was brownish-yellow. Before an antibacterial test, the peel extract went through a contamination test to ensure that it was free from contaminants.

\section{Antibacterial activity test of yellow kepok banana peel extract}

Preliminary research was carried out conducted to determine the treatments' concentration range more thoroughly. The results indicated that bacterial colonies were no longer found at the extract concentration of $25 \%$, while the lowest number of colonies was found at a concentration of $12.5 \%$. From these results, the study used 6 treatment groups of which the peel extract concentrations were $17.5 \%$, $15 \%, 12.5 \%, 10 \%, 7.5 \%, 5 \%$, and 2 control groups with three repetitions each.

The method employed in this study was tube dilution [10]. Porphyromonas gingivalis was incubated for 24 hours at $37^{\circ} \mathrm{C}$. The incubation was performed on anaerobic jar, and the colony was put into BHI-B (Brain Heart Infusion Broth) until the amount obtained is in proportion with Brown III solution with a concentration of $10^{8} \mathrm{CFU} / \mathrm{ml}$. The solution was diluted again until it reached $10^{6} \mathrm{CFU} / \mathrm{ml}$.

Eight sterile tubes were prepared. Each was filled with distilled water, $0.2 \%$ chlorhexidine gluconate, yellow kepok banana peel extract of $17.5 \%, 15 \%$, $12.5 \%, 10 \%, 7.5 \%$ and $5 \%$ as much as $1 \mathrm{ml}$, and then $1 \mathrm{ml}$ of each bacterial suspension was added. All tubes were incubated in an anaerobic jar for 24 hours at $37^{\circ} \mathrm{C}$. The Minimum Inhibitory Concentration (MIC) value was determined by measuring the tubes' turbidity using black striped white paper; the control tubes were used as a comparison. After that, each tube was given a level based on its clarity.

After the MIC value was determined, the tubes starting to look clearer were taken with a loop, etched on BHI-A (Brain Heart Infusion Agar), and incubated in an anaerobic jar for 24 hours at $37^{\circ} \mathrm{C}$. The bacterial colonies that grew were counted using a colony counter. Minimum Bactericidal Concentration (MBC) was determined by calculating $0.1 \%$ of OI (original inoculum), which was a bacterium with a concentration of $10^{6} \mathrm{CFU} / \mathrm{ml}$ implanted in agar culture media before incubation.

\section{RESULTS AND DISCUSSIONS}

The MIC value was determined by looking at the tubes' turbidity, which was followed by giving a level on each. The results revealed that (1) tubes containing yellow kepok banana peel extract with concentrations of $5 \%$ and $7.5 \%$ had the same turbidity as negative control tubes; and (2) tubes containing the peel extract with concentrations of $12.5 \%, 15 \%$ and $17.5 \%$ showed clearer results; while (3) the tube containing the peel extract with a concentration of $10 \%$ was the color change borderline of turbid to clear (Figure 1). Thus, the MIC result was obtained from yellow kepok banana peel extract against Porphyromonas gingivalis bacteria at a concentration of $10 \%$.

Table 1. Extract Turbidity Score

\begin{tabular}{ccccc}
\hline \multirow{2}{*}{ Concentration } & \multicolumn{3}{c}{ Number of colonies } & Average \\
\cline { 2 - 4 } score
\end{tabular}

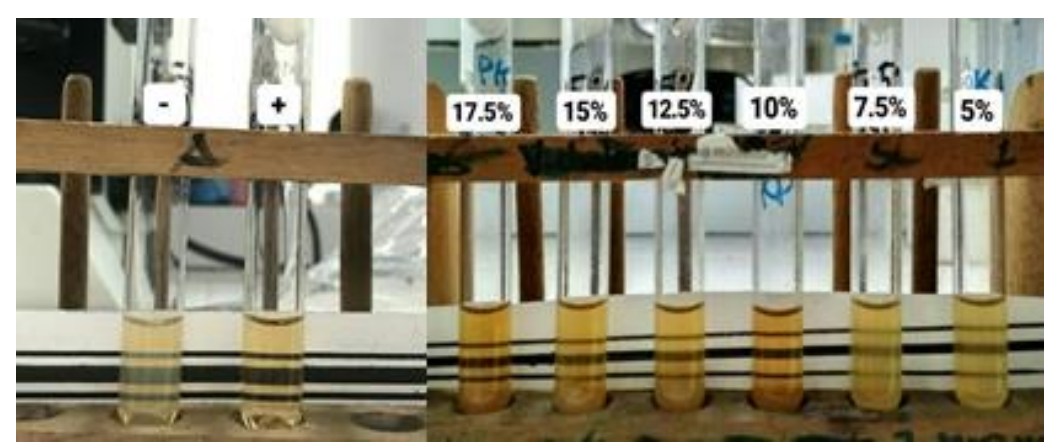

Figure 1. The turbidity level of each tube 
The MBC value of yellow kepok banana peel extract against Porphyromonas gingivalis indicated that if the colony growth was 0 or less than $0.1 \%$ of OI (Fig.2). The average results of calculating Porphyromonas gingivalis colonies using the colony counter were presented in Table 2 . The OI value was 253.3 CFU/ml, so $0.1 \%$ of it was 0.253 . Based on these requirements, the peel extract with a concentration of $17.5 \%$ was the MBC.

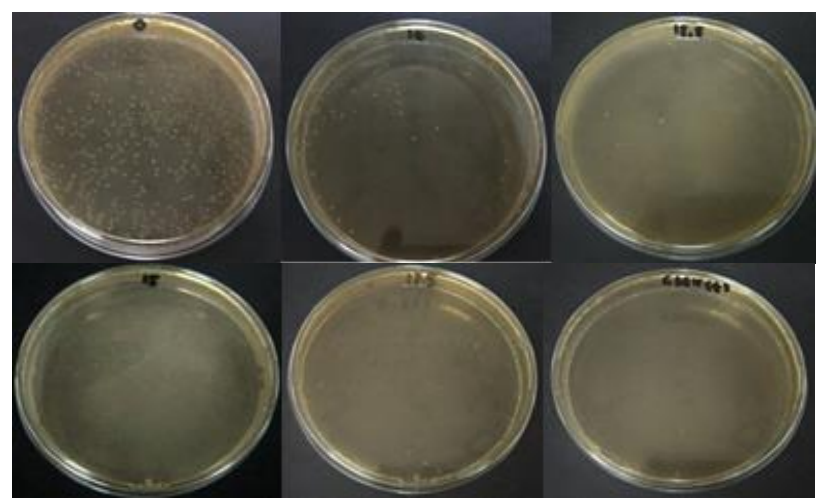

Figure 2. The colony growth of each extract concentration

\begin{tabular}{ccccc}
\hline \multirow{2}{*}{ Concentration } & \multicolumn{3}{c}{ Number of colonies } & \multirow{2}{*}{ Average } \\
\cline { 2 - 4 } & I & II & III & \\
\hline K(-) & 281 & 254 & 225 & 253.33 \\
K (+) & 0 & 0 & 0 & 0 \\
$\mathbf{1 0} \%$ & 136 & 129 & 110 & 125 \\
$\mathbf{1 2 . 5} \%$ & 95 & 65 & 88 & 82.6 \\
$\mathbf{1 5} \%$ & 26 & 51 & 23 & 33.33 \\
$\mathbf{1 7 . 5} \%$ & 0 & 0 & 0 & 0 \\
\hline
\end{tabular}

Data analysis was performed based on the tubes' turbidity and the number of bacterial colonies on BHI-A media. Research data for MIC were analysed using Kruskal Wallis to determine differences in various concentrations of yellow kepok banana peel extract on tube turbidity. In the Kruskal Wallis test, the result showed a significance value of 0.011 (p $<0.05$ ), of which the difference was significant.

After the Kruskal Wallis test, the Mann Whitney test was performed to determine which groups were significantly different. The group was significantly different if the significance value was $<0.05$; They were the control group (-) and control group (+), control group (-) and 10\% concentration, control group (-) and $17.5 \%$ concentration, control group (+) and $5 \%$ concentration, control group $(+)$ and $7.5 \%$ concentration, $5 \%$ concentration and $10 \%$ concentration, as well $5 \%$ concentration and $17.5 \%$ concentration. The $12.5 \%$ and $15 \%$ concentrations were not significantly different from positive control and negative control groups. After the Mann Whitney test, the Spearman correlation test was conducted to determine the relationship between variables. In this test, the result indicated significance value $\mathrm{Sig}$ (2-tailed) $0.00<0.05$; thus, there was a relationship between extract concentration variables with turbidity. The correlation coefficient was 0.790 , meaning that the level of correlation between the concentration and turbidity variables was 0.790 (very strong). The correlation coefficient had a positive value of 0.790 so that the relationship between the two variables was unidirectional

Research data for MBC were analysed using Kruskal Wallis to determine differences in various concentrations of yellow kepok banana peel extract on the number of colonies. In the Kruskal Wallis test, the result revealed a significance value of 0.005 (p $<0.05$ ), showing significant differences. Following this, the Mann Whitney test was performed to find out which groups were significantly different. The test results indicated that the number of bacterial colonies was almost entirely different significantly, excluding the $17.5 \%$ concentration and control (+). Next, the Spearman correlation test was performed to determine the relationship between variables. In this test, the significance value of Sig (2-tailed) 0.00 $<0.05$ was obtained, indicating that there was a relationship between the extract concentration variable and the number of colonies. Moreover, the correlation coefficient was -0.977 , meaning that the level of correlation between the concentration variables with the number of colonies was -0.977 (very strong), showing that the relationship between the two variables was not unidirectional the relation. Thus, increasing the concentration would decrease the number of bacterial colonies.

The extraction process of yellow kepok banana peel was carried out at Balai Materia Medica, UPT Balai Kesehatan of East Java Province, Batu. Maceration was chosen as the extraction method since it is a simple method on a small scale of work and can avoid damaging thermolabile compounds [11]. The solvent used was methanol as it is a universal solvent with a high yield value [12], indicating that the methanol solvent can extract more organic components or compounds having higher polarity properties [12,13]. These include flavonoids, tannins, saponins and triterpenoids contained in banana peel extract [8]. Methanol solvents also have a better ability than acetone, chloroform, aquadest, ethyl acetate and hexane in dissolving several active compounds including flavonoids, saponins, and tannins [14].

The MIC value of yellow kepok banana peel extract against Porphyromonas gingivalis was obtained at a concentration of $10 \%$, while the MBC value of the peel extract against Porphyromonas gingivalis was obtained at a concentration of $17.5 \%$. The concentration of peel extract on Porphyromonas gingivalis rose with increasing antibacterial activity from MIC to MBC; this is in line with Gunawan 
(2007) stating that the antibacterial compound will increase its activity from bacteriostatic to bactericidal if the concentration is increased [15].

Spearman correlation test was conducted to determine the relationship between variables; it was found that there was a relationship between the extract concentration variables and the number of colonies. The level of correlation was very strong and negative so that the increasing concentration of the extract used will decrease the number of bacterial colonies. It is also expected that the bioactive compounds in yellow kepok banana peel extract will increase in number allowing the gram-negative bacterial cell membranes' (Porphyomonas gingivalis) ability to penetrate the lipopolysaccharide layer to increase [16].

The ability of yellow kepok banana peel extract to inhibit growth and kill the bacteria Porphyromonas gingivalis was increased because the levels of substances contained therein also increased. The first active compound found in the peel extract was flavonoids. Some of the antibacterial mechanisms of flavonoids are inhibiting the synthesis of nucleic acids, the function of cytoplasmic membranes, metabolic processes, the attachment and formation of biofilms, causing changes in membrane permeability, and they can weaken microbial pathogenicity [17]. Porphyromonas gingivalis is a Gram-negative bacterium that forms biofilms. Biofilm is one of the virulence factors affecting the pathogenicity and the presence of Porphyromonas gingivalis in periodontal pockets [18]. Flavonoids in yellow kepok banana peel extract will affect the ability of Porphyromonas gingivalis in forming biofilms so that pathogenicity and its presence in periodontal pockets can decrease.

The second active compound found in yellow kepok banana peel was tannin. Antibacterial mechanisms of tannins include inhibiting bacterial extracellular enzymes and affecting bacterial metabolism by inhibiting oxidative phosphorylation [19]. Bacterial metabolism is the activity of bacteria producing energy to grow and develop [16]. The growth and development of Porphyromonas gingivalis were highly affected by tannin as the substance disturbed its metabolism.

Saponin was the third active compound found in yellow kepok banana peel extract. Its antibacterial mechanism is by increasing the permeability of cell membranes [9]. This increase causes the cell membrane to become unstable and ultimately results in cell haemolysis, resulting in the release of important components in bacterial cells so that the bacteria will die faster [16].

The next compound found in yellow kepok banana peel extract and had the same mechanism as saponins were alkaloids and triterpenoids. Cell membranes can be damaged when antibacterial active compounds react with the active side of the membrane, or by dissolving lipid constituents and increasing their permeability. The bacterial cell membrane consists of phospholipids and protein molecules; with an increase in permeability, the antibacterial compound can enter the bacterial cell and can lyse the cell membrane or coagulate the bacterial cell's cytoplasm [16].

Some of the research results of yellow kepok banana peel antibacterial effect on several bacteria, including antibacterial test against $S$. aureus and $E$. coli, demonstrated that the n-butanol extract of $10 \%$ yellow kepok banana peel extract had a MIC value of $0.5 \%$ for S.aureus, and $0.1 \%$ for E. coli [20]. Another study conducted by Nursanti et al (2018) revealed that the kepok banana peel extract with a concentration of $25 \%$ could inhibit S. aureus, whereas, in E. coli, the peel extract was effective at a concentration of $10 \%$ and $25 \%$ as it could not inhibit its growth [7].

\section{CONCLUSION}

Yellow kepok banana peel extract proved to be effective as an antibacterial for Porphyromonas gingivalis in vitro. The MIC value of the peel extract was obtained at a concentration of $10 \%$, while the MBC value was obtained at a concentration of $17.5 \%$. There was a relationship between increasing the extract concentration with increasing tube clarity and decreasing the number of Porphyromonas gingivalis colonies.

\section{REFERENCES}

1. Newman, M.G., Carranza, F.A., Takey,H.H. 2015. Carranza's Clinical Periodontology, $12^{\text {th }}$ $E d$. California: W.B Saunders Company.

2. Alibsyah,Z.M., Andayani,R., Farhana,A.. 2016 Potensi Antibakteri Ekstrak Jahe (Zingiber Officinale Roscoe) Terhadap Porphyromonas gingivalis secara In Vitro, Journal of Syiah Kuala Dentistry Society, 1(2); 147-52.

3. Prasanna S.G.Vishnu, Lakshmanan Reema. 2016. Characteristics, Uses and Side effects of Chlorhexidine- A Review. IOSR Journal of Dental and Medical Sciences 15 (6) Ver. III .PP 57-59.

4. Ismail. 2015. Faktor yang mempengaruhi Keputusan Masyarakat Memilih Obat Tradisional Di Gampong Lam Ujong. Idea Nursing Journal. VI(1); 7-14.

5. Kementerian Pertanian. 2014. Outlook Komoditi Pisang, Jakarta. P. 30-32.

6. Imam Mohammad Zafar, Akter Saleha. 2011. Musa paradisiaca L. and Musa sapientum L.: A Phytochemical and Pharmacological Review. 
Journal of Applied Pharmaceutical Science 01 (05) p 14-20.

7. Nursanti A, Suparto I H, Kemala T. 2018. Uji Aktivitas Antibakteri Limbah Kulit Pisang Kepok (Musa acuminata x balbisiana), Kulit Pisang Uli (Musa Paradisiaca Sapientum), dan Kulit Pisang Nangka (Musa sp L). Al-Kimia Vol 6(2) 125-130.

8. Lumowa Sonja V.T., Bardin Syahril. 2018. Uji fitokimia kulit pisang kepok (Musa paradisiaca 1.) bahan alam sebagai pestisida nabati berpotensi menekan serangan serangga hama tanaman umur pendek. Jurnal Sains dan Kesehatan. Vol 1 (9) p. 465-69.

9. Saxena M, Saxena J, Nema R, Singh D, Gupta A. 2013. Phytochemistry of Medicinal Plants. Journal of Pharmacognosy and Phytochemistry Vol 1 (6) p. 168-82.

10. Noorhamdani, Sanarto S, Sumarno, Sjoekoer MD, Roekistiningsih, Sri W, Dewi S, Dwi YN, Yuanita M, Dewi E, Siwipeni IR, Bethania SF. 2017. Bakteriologi medik ed. Ketiga. IRDH: Purwokerto, 108-109.

11. Mukhriani. 2014. Ekstraksi, Pemisahan Senyawa, dan Identifikasi Senyawa Aktif, Jurnal Kesehatan, VII (2) p 361-67.

12. Romandanu, Rachmawati,S.H., Lestari,S.D. 2014. Pengujian Aktivitas Antioksidan Ekstrak Bunga Lotus (Nelumbo nucifera). Fishtech, III (01) p.1-5.

13. Pane E.R. 2013. Uji Aktivitas Antioksidan dari Ekstrak Metanol Kulit Pisang Raja (Musa paradisiaca sapientum). Valensi, 3(2) p.76-81.

14. Dhawan D, Gupta J. 2017. Comparison of Different Solvents for Phytochemical Extraction Potential from Datura metel Plant Leaves. Int. J. Biol. Chem., 11 (1) p.17-22.

15. Gunawan, S.G., Setiabudi,R., Nafrialdi, Elizabeth., 2007. Farmakologi dan Terapi. Edisi 5. Balai Penerbit FKUI:Jakarta

16. Brooks GF, Carol KC, Butel JS, Morse SA, Mietzner TA. 2013. Jawetz, melnick \& adelberg Medical Microbiology 26th edition.The Mc Graw-Hill Companies. US p.55, 77.

17. Xie Yixi, Yang Weijie, Tang Fen, Chen Xiaoqing, Ren Licheng. 2015. Antibacterial Activities of Flavonoids: Structure-Activity Relationship and Mechanism. Current Medicinal Chemistry Vol 22(1) p. 132-49.

18. He Lu, Wang Hongyuan, Zhang Ru, Li Hong. 2019. The regulation of Porphyromonas gingivalis biofilm formation by ClpP. Biochemical and Biophysical Research Communications Vol 509(2), p. 335-340.

19. Ogawa S, Yazaki Y. 2018. Tannins from Acacia mearnsii De Wild. Bark: Tannin Determination and Biological Activities. Molecules 23; $837 \mathrm{p}$ 1-18.

20. Wahyuni NKDMS, Rita WS, Asih IARA. 2019. Aktivitas antibakteri ekstrak kulit pisang kepok kuning (Musa paradisiaca l.) Terhadap bakteri Staphylococcus aureus dan Escherichia coli serta penentuan total flavonoid dan fenol dalam fraksi aktif. Jurnal kimia 13 (1) p. $9-15$. 